\title{
Rapid Assesment Analisis Beban Kerja Perawat Ruang Isolasi Rawat Inap Non ICU Covid-19 di Rumah Sakit Umum Daerah Cengkareng
}

\section{Rapid Assessment Analysis of Nurse Workload Isolation Room Non ICU Covid- 19 Inpatient at Cengkareng Regional General Hospital}

\author{
Ni Putu Retno Ariani ${ }^{1}$, Yaslis Ilyas ${ }^{2}$ \\ ${ }^{1}$ Pasca Sarjana Kajian Administrasi Rumah Sakit Indonesia, FKM, Universitas Indonesia \\ ${ }^{2}$ Departemen Administrasi dan Kebijakan Kesehatan, FKM, Universitas Indonesia \\ E-mail: ennoinz@gmail.com; yaslisilyas@gmail.com
}

\begin{abstract}
ABSTRAK
Pada masa pandemi Covid-19, tenaga keperawatan merupakan profesi yang sangat dibutuhkan dalam penanganan pasien yang terkonfirmasi Covid-19. Untuk memenuhi kebutuhan jumlah tenaga perawat maka perlu dilakukan analisa beban kerja dan selanjutnya dapat dilakukan perhitungan kebutuhannya. Tujuan penelitian mendeskripsikan dan mengidentifikasi beban kerja perawat di ruang isolasi rawat inap non ICU pelayanan Covid-19 di RSUD Cengkareng yang merupakan salah satu rumah sakit rujukan Covid-19. Penelitian ini menggunakan metode kuantitatif dengan pendekatan observasional, data penelitian diambil melalui pengamatan langsung dan wawancara mendalam yang dilakukan selama kurun waktu 5 hari di ruang isolasi rawat inap non ICU. Perhitungan beban kerja menggunakan metode Ilyas, dimana informasi yang dihasilkan untuk mengambil keputusan dapat dipercaya karena setiap transaksi bisnis dapat diukur secara cepat dengan tingkat akurasi yang tinggi. Dengan menghitung beban kerja ini dapat memperkirakan kebutuhan tenaga perawat yang diperlukan dalam perencanaan sumber daya manusia. Hasil perhitungan yang didapatkan yaitu berdasarkan data pasien per-Desember 2020, jumlah pasien yang dirawat di ruang isolasi non ICU untuk pasien Covid-19 berjumlah 251 orang, sedangkan tenaga perawat yang terdiri dari perawat RSUD Cengkareng dan perawat relawan berjumlah 171 orang. Berdasarkan data tersebut, analisa beban kerja dengan metode Ilyas didapatkan nursing time perawat ruang isolasi non-ICU untuk pasien Covid-19 adalah 3,5 jam, dan perhitungan kebutuhan tenaga perawat sebesar 178 orang. Penambahan jumlah tenaga perawat di ruang isolasi rawat inap non ICU di RSUD Cengkareng masih dibutuhkan.
\end{abstract}

Kata Kunci : Analisa Beban Kerja, Kebutuhan Tenaga Perawat, Metode Ilyas

\begin{abstract}
During the Covid-19 pandemic, nursing staff is a profession that is very much needed in handling patients who are confirmed Covid-19. To have the needs of the number of nurses, it is necessary to analyze the workload and then calculate the needs.This research aims to describe and identify nurses' workload at non-ICU isolation rooms for Covid-19 patients at Cengkareng Regional General Hospital (RSUD Cengkareng) in West Jakarta, which is one of Covid-19 referral hospitals. Method: This is a quantitative observational research. The data was obtained through direct observation and in-depth interviews that were conducted for five days at the hospital's non-ICU isolation rooms for Covid-19 patients. The workload quantification uses the Ilyas method, which quickly measures in detail every business transaction with a high degree of accuracy to generate reliable information for decision making process. By quantifying this workload, it can estimate the need for nurses required in human resource planning. Outcome: Following the quantification that was based on patient data per December 2020, the total number of patients at the hospital's non-ICU isolation rooms for Covid-19 patients were 251 people. However, the number of RSUD Cengkareng's nurses and volunteer nurses combined were 171 people. Following workload analysis quantification using Ilyas method, the nursing time for the non-ICU isolation rooms for Covid-19 patients is 3,5 hour, while 178 nurses are needed for the rooms. Conclusion: There was a addition needs for nurses for the non-ICU isolation rooms for Covid-19 patients at RSUD Cengkareng, therefore the rooms need additional nurses.
\end{abstract}

Keywords: Workload analysis, Nurses Need, Ilyas Method. 


\section{PENDAHULUAN}

Organisasi Kesehatan Dunia (WHO) secara resmi menyatakan virus corona Covid-19 sebagai pandemi global sejak bulan Maret 2020, dikarenakan peningkatan jumlah kasus mencapai 13 kali lipat di luar China dengan peningkatan secara drastis jumlah negara terdampak. Pandemi Covid-19 menjadikan profesi perawat mempunyai fungsi yang sangat penting. Dalam penanganan pasien Covid-19 membutuhkan penambahan jumlah tenaga keperawatan agar rumah sakit dapat menyelenggarakan operasionalnya sebagai rumah sakit rujukan. Pada puncak kasus penyebaran Covid-19, ketersediaan perawat masih sangat kurang dalam menangani pasien yang terinfeksi (Arief, 2020). Dengan adanya peningkatan jumlah kasus yang terus-menerus, maka dibutuhkan ruang perawatan isolasi untuk rawat inap dan sumber daya manusia yang memadai. Gubernur DKI Jakarta mengeluarkan Surat Keputusan Gubernur DKI Jakarta Nomor 378 Tahun 2020 tentang Penetapan RS Rujukan Penanggulangan Covid-19 pada tanggal 08 April 2020, dimana RSUD Cengkareng menjadi salah satu RS rujukan tersebut. RSUD Cengkareng telah memiliki fasilitas isolasi rawat inap yang cukup besar, hal imi juga harus didukung dengan tenaga medis yang mumpuni.

Manajemen keperawatan adalah suatu proses dalam memberikan pengobatan, asuhan dan bantuan yang dilakukan oleh sumber daya keperawatan terhadap para pasien (Gillies, 1999). Manajemen asuhan keperawatan yang terdapat pada manajemen keperawatan, harus dapat diterapkan oleh para perawat dalam melayani pasien. Tujuan manajemen keperawatan yaitu agar dapat mengarahkan kegiatan yang direncanakan, mengatasi masalah manajerial dan dapat mencapai tujuan organisasi. Selain itu terdapat peningkatan metode kerja para perawat sehingga pekerjaan yang dilakukan lebih efektif dan efisien karena waktu kerja yang sia - sia dan duplikasi tenaga serta usaha dapat diminimalisir.

Perencanaan SDM rumah sakit pada masa pandemi sangat penting dalam keberlangsungan suatu organisasi untuk menjawab tantangan di masa depan yang berkaitan dengan kinerja, kualitas dan produktivitas rumah sakit. Menurut Ilyas, 2017, pengertian perencanaan SDM adalah proses memperkirakan jumlah SDM yang dibutuhkan untuk menjalankan pelayanan kesehatan yang didasarkan pada posisi, keterampilan, dan perilaku. Fungsi dan beban kerja pelayanan kesehatan terhadap pasien merupakan dasar dalam perencanaan kebutuhan SDM keperawatan. Dalam menganalisa beban kerja perlu dilakukan pengamatan terhadap beban kerja yang dapat diselesaikan dengan sumber daya dan waktu yang tepat (Ilyas, 2017). Metoda ini dapat menghitung 
Ni Putu Retno Ariani, Yaslis Ilyas : Rapid Assesment Analisis Beban Kerja ...

beban kerja personel dengan cepat dengan tingkat akurasi yang tinggi sehingga menghasilkan informasi yang dapat dipercaya untuk pengambilan keputusan manajemen. Pendekatan yang diterapkan dalam metode ini yaitu demand, dimana beban kerja yang dihitung untuk dapat menghasilkan produk dan jasa dalam waktu yang dibutuhkan harus dikerjakan berdasarkan permintaan, sehingga setiap tenaga kerja dalam unit organisasi harus melakukan volume transaksi bisnis tersebut. Berdasarkan Keputusan Menkes Nomor 81 Tahun 2004 tentang Pedoman Penyusunan Perencanaan Sumber Daya Manusia Kesehatan di Tingkat Provinsi, Kabupaten/Kota serta ditingkat Rumah Sakit, memerintahkan bahwa dalam penyusunan kebutuhan SDM kesehatan, metode yang digunakan harus berdasarkan empat faktor, yaitu kebutuhan epidemiologi penyakit, permintaan (demand) akibat beban pelayanan kesehatan, sarana kesehatan yang ditetapkan, serta penetapan standar atau rasio terhadap nilai tertentu.

Untuk pengoperasian rumah sakit darurat, yang termasuk juga pelayanan terhadap pasien dan berbagai tes massal yang berkaitan dengan Covid-19, tenaga Keperawatan berperan penting dalam pandemi Covid-19 ini yang membutuhkan penambahan tenaga perawat (Indrasari, 2020). Secara umum, peranan perawat dalam segi promotif, preventif, dan edukatif juga termasuk dalam asuhan keperawatan terutama pada kondisi wabah Covid-19 (Hernawan, 2020). Menurut Supyono, pengelolaan SDM keperawatan dalam menangani Covid-19 dibagi dalam beberapa tim dengan jumlah jam kerja 5 jam sehari yang bekerja selama 7 hari, dengan jadwal yang terdiri dari observasi, dinas luar/libur dan MCU. Menurut Astuti, 2020, pengalaman perawat selama bertugas di area akut rumah sakit selama pandemi Covid-19 ditemukan bahwa faktor fisik adalah faktor utama yang dialami perawat saat menjalankan tugas seperti pengelolaan beban kerja yang tinggi. Oleh karena itu diperlukan sistem pengelolaan tenaga perawat dan pemenuhan sarana yang sesuai standar seperti alat perlindungan diri sehingga menurunkan risiko terpapar dan tertular. Aspek psikologis perawat dalam menangani pasien Covid-19 juga harus diperhatikan karena seringkali timbul gangguan psikologi seperti kecemasan, gugup, sering menangis, gangguan pencernaan, sulit tidur dan tidak nafsu makan (Astuti, 2020).

Instruksi Gubernur Daerah Khusus Ibukota Jakarta nomor 55 Tahun 2020 tentang Peningkatan Kapasitas Perawatan Bagi Pasien Corona Virus Disease 2019 (Covid-19) Pada Rumah Sakit Umum Daerah dan Rumah Sakit Rujukan Penanggulangan Corona Virus Disease 2019 (Covid-19 ) menetapkan RSUD Cengkareng sebagai rs rujukan yang menyediakan ruang isolasi rawat inap non ICU yang diperuntukkan pasien dengan 
penyakit Covid-19 dengan kapasitas sebanyak 292 bed, yang telah terisi mencapai 251 bed. Sumber Daya Manusia keperawatan di ruang isolasi rawat inap non ICU berjumlah 171 terdiri dari perawat dari RSUD Cengkareng dan relawan yang berasal dari Dinas Kesehatan. Manajemen keperawatan di ruang isolasi rawat inap non-ICU ini di atur oleh perawat penanggung jawab dan komite keperawatan. Perbandingan jumlah perawat dengan pasien yaitu 1 : 5. Pengaturan jam jaga ruangan disusun sesuai jam kerja sebanyak 37,5 jam per minggu. Dalam satu hari terdapat 3 shift yaitu dinas pagi pada pukul 07.00 - 14.00, dinas siang pada pukul 14.00 - 21.00 dan dinas malam pada pukul 21.00 - 07.00. Setiap shift terdiri dari 7-8 perawat dan dalam setiap shift dibagi dalam dua sesi yaitu sesi 1 dan sesi 2 . Tim sesi 1 dan 2 masing-masing berjumlah 3-4 orang yang akan masuk secara bergantian untuk melakukan asuhan keperawatan. Tim sesi 1 akan masuk ke ruang perawatan menggunakan APD level 3 dan melakukan asuhan keperawatan selama di dalam ruangan. Sedangkan tim sesi 2 yang akan melakukan monitoring di nurse station. Tiap tim sesi akan berada dalam ruang perawatan selama 3,5 jam, secara bergantian. Pola shift dinas yang diterapkan kepada perawat adalah 2 hari dinas pagi, 2 hari dinas siang, 2 hari dinas malam, 1 hari lepas dinas dan 1 hari libur. Setelah dinas selama 14 hari, maka perawat berhak untuk libur selama 3 hari. Dalam satu hari jumlah perawat yang bekerja diruang isolasi rawat inap sebanyak 21-24 orang.

\section{METODE}

Penelitian ini menggunakan metode kuantitatif dengan pendekatan observasional, data penelitian diambil melalui hasil observasi langsung dan wawancara mendalam terhadap perawat ruang isolasi non ICU Covid-19 . Observasi dilakukan untuk mengetahui jumlah waktu yang dihabiskan oleh perawat isolasi rawat inap non ICU Covid-19 selama memberikan layanan keperawatan bagi pasien baik secara langsung maupun tidak langsung. Observasi dan wawancara dilakukan selama kurun waktu 5 hari di ruang isolasi rawat inap non ICU, menggunakan metode Ilyas yang mengukur beban kerja dengan merinci setiap transaksi bisnis yang terdiri dari waktu dan volume transaksi pada suatu unit dalam waktu 24 jam (3 shift). Wawancara secara mendalam juga dilakukan kepada ketua komite keperawatan, perawat ruang isolasi rawat inap non ICU, dan perawat penanggung jawab. Perhitungan analisis beban kerja di ruang isolasi rawat inap Covid-19, dilakukan dengan menggunakan metode observasi dan metode Yaslis Ilyas. Formula Beban Kerja Ilyas terdiri dari komponen sbb : Beban kerja/hari : B.Ki-j =JT X WT, dimana B Ki-j adalah Jenis Beban Kerja, JT merupakan Jumlah Transaksi per 
Ni Putu Retno Ariani, Yaslis Ilyas : Rapid Assesment Analisis Beban Kerja ...

hari dan WT adalah Waktu (menit atau jam) untuk setiap jenis transaksi. Perawat merupakan proporsi yang paling besar di rumah sakit, diperkirakan sekitar $75 \%$ dari populasi personel di rumah sakit (Ilyas, 2017). Formula Perhitungan ini digunakan hanya untuk menghitung kebutuhan perawat di ruang rawat inap, namun saat ini telah disediakan perhitungan untuk unit lainnya. Dengan perhitungan sebagai berikut : Tenaga perawat : A X B X 365 / 255X jam kerja/hari. Sebagai keterangan, A adalah jam perawatan/24 jam, B merupakan sensus Harian (BOR X jumlah tempat tidur), dan jam kerja/hari adalah 7 jam per hari dan 365 merupakan Jumlah hari kerja selama setahun, serta 255 adalah hari kerja efektif perawat/tahun

\section{HASIL DAN PEMBAHASAN}

Lonjakan pasien akibat pandemi Covid-19, mengharuskan rumah sakit terutama yang menjadi rumah sakit rujukan untuk untuk menambah ruangan yang menjadi ruang isolasi rawat inap dan dilengkapi dengan sumber daya serta peralatannya, sehingga mempengaruhi kebijakan manajemen rumah sakit. Kapasitas ruang perawatan dibeberapa rumah sakit telah mencapai lebih dari $65 \%$, diikuti oleh keterbatasan tenaga kesehatan, yang dapat juga ditimbulkan karena adanya kluster penularan di rumah sakit (Dewi, Listya, 2020). Ruang isolasi rawat inap non ICU di RSUD Cengkareng, terdiri dari 171 perawat, dengan terbagi menjadi 3 shift per harinya dan setiap shift mempunyai waktu selama 7 atau 8 jam. Setiap shift terdiri dari 7-8 perawat, dimana dibagi menjadi 2 sesi yang masing-masing sesinya terdiri dari 3-4 orang. Jumlah pasien di ruang isolasi rawat inap non ICU sebanyak 251 orang dengan nilai BOR sebesar 85\%,dimana data ini diambil pada bulan Desember 2020.

Berdasarkan data yang didapatkan, nursing time untuk ruang isolasi rawat inap COVID-19 non ICU adalah : 3,5 jam. Dengan metode Ilyas, didapatkan perhitungan tenaga perawat : $(\mathrm{A} \times \mathrm{B} \times 365) / 255 \times \mathrm{jam}$ kerja/hari $=(3,5 \times(0,85 \times 292) \times 365)$ $/ 255 \times 7=317075,5 / 1785=177,6$, dengan catatan 255 adalah hari kerja efektif formula sifting 3/4. Hasil analisis beban kerja perawat isolasi non icu Covid-19, didapatkan nursing time : 3,5 jam perhari, kemudian dilakukan perhitungan jumlah kebutuhan perawat yaitu 178 orang. Hasil wawancara dengan ketua komite keperawatan, jumlah tenaga perawat yang ada di ruang isolasi rawat inap non-ICU Covid-19 berjumlah 171 orang yang terdiri dari perawat RSUD Cengkareng dan Relawan. Dengan data tersebut menggambarkan adanya kekurangan tenaga keperawatan. Hal ini dapat dikarenakan meningkatnya kasus Covid-19, sehingga menyebabkan penuhnya ruang perawatan dan 
meningkatkan kebutuhan perawat baik yang berasal dari RSUD Cengkareng maupun relawan.

Untuk mengantisipasi meningkatnya beban kerja dan kebutuhan sejumlah perawat, maka pihak manajemen RSUD Cengkareng diharapkan mengajukan kembali permintaan tenaga relawan atau memperpanjang sistem kontrak dari tenaga relawan tersebut. Selain itu penanganan kasus Covid-19 oleh pemerintah juga dapat berpengaruh terhadap meningkatnya jumlah kasus Covid-19, dengan menerapkan kebijakan-kebijakan yang diterapkan terdiri dari mencegah penularan dengan menjalankan protokol kesehatan, melakukan screening terhadap kasus baru, melaksanakan PSBB, memberikan bantuan sosial dan pencegahan dengan vaksin yang mulai bulan Januari 2021 mulai disebarluaskan di seluruh Indonesia. Dengan menekan sejumlah kasus, diharapkan dapat mengurangi kunjungan terhadap pelayanan isolasi rawat inap dan ICU di RSUD Cengkareng sebagai RS rujukan, sehingga beban kerja tenaga kesehatan khusunya keperawatan dapat sesuai dengan ketentuan-ketentuan yang berlaku.

\section{SIMPULAN}

Pandemi Covid-19 membawa pengaruh yang cukup besar terhadap dunia kesehatan, khususnya tenaga kesehatan yang secara langsung menangani kasus Covid-19 . Penanganan pemerintah dalam masa pandemi Covid-19 dengan mengeluarkan beberapa kebijakan, seperti kebijakan yang dikeluarkan pemerintah daerah dengan Instruksi Gubernur Daerah Khusus Ibukota Jakarta nomor 55 Tahun 2020 tentang Peningkatan Kapasitas Perawatan Bagi Pasien Corona Virus Disease 2019 (Covid-19) Pada Rumah Sakit Umum Daerah dan Rumah Sakit Rujukan Penanggulangan Corona Virus Disease 2019 (Covid-19 , dimana RSUD Cengkareng ditunjuk sebagai RS rujukan yang menangani pasien dengan Covid-19 .

Adanya peningkatan kasus yang signifikan, RSUD Cengkareng sebagai salah satu RS rujukan menyediakan ruang isolasi rawat inap khusus dan ICU untuk menangani pasien dengan Covid-19. Selain membutuhkan ruang perawatan khusus, RSUD Cengkareng juga membutuhkan tenaga kesehatan terutama keperawatan sebagai salah satu garda terdepan dalam jumlah yang cukup besar, sehingga dibutuhkan bantuan tenaga relawan yang berasal dari Dinas Kesehatan dan Dinas Kesehatan DKI Jakarta. Berdasarkan data pasien per-Desember 2020, jumlah pasien yang dirawat di ruang isolasi non ICU berjumlah 251 orang, sedangkan tenaga perawat termasuk relawan berjumlah 171 orang. Dengan perhitungan analisa beban kerja metode Ilyas didapatkan nursing time 
Ni Putu Retno Ariani, Yaslis Ilyas : Rapid Assesment Analisis Beban Kerja ...

perawat isolasi non Covid-19 sebesar 3,5 jam, dan kebutuhan tenaga perawat sebesar 178 orang. Dengan kondisi seperti ini, masih diperlukan tenaga relawan untuk membantu tenaga di RSUD cengkareng dalam menangani pasien di ruang isolasi rawat inap non ICU. Selain itu, kebijakan-kebijakan pemerintah yang terus diperbaharui yaitu dengan menyediakan vaksin Covid-19, dapat meminimalisir penularan penyakit yang nantinya akan menurunkan jumlah kasus.

\section{UCAPAN TERIMA KASIH}

Terima kasih kepada Prof. DR. Yaslis Ilyas, DRG. MPH. HIA. MHP. AAK. Sebagai Pembimbing Akademik Fakultas Kesehatan Masyarakat Universitas Indonesia yang telah memberikan bimbingannya dan RSUD Cengkareng beserta para staf yang telah membantu proses penelitian ini sehingga berjalan dengan baik.

\section{DAFTAR PUSTAKA}

Astuti, Tri, 2020. Implikasi Manajemen Keperawatan dalam Penanganan Pasien Corona Virus Disease-19 (Covid-19 ) : Literatur Review. Jurusan Keperawatan Politeknik Kemenkes, Surakarta.

Gillies, 1999. Nursing Management : A System Approach, Philadelphia : WB Sanders Company.

Hernawan, Wawan,2020. Pengelolaan SDM Keperawatan Selama Pandemi COVID-19, Kementerian Kesehatan RI, Jakarta Selatan.

Ilyas, Yaslis, 2017. Perencanaan SDM Rumah Sakit, Teori, Metode, dan Formula, Fakultas Kesehatan Masyarakat Universitas Indonesia, Depok.

Indrasari,Meithiana, 2020. COVID-19 dan Urgensi SDM Keperawatan, Universitas Dr. Soetomo, Surabaya.

Intruksi Gubernur DKI Jakarta Nomor 55 Tahun 2020 tentang Peningkatan Kapasitas Perawatan Bagi Pasien Corona Virus Disease 2019 (Covid-19) Pada Rumah Sakit Umum Daerah dan Rumah Sakit Rujukan Penanggulangan Corona Virus Disease 2019.

Julianto, Mito, 2016. Peran dan Fungsi Manajemen Keperawatan dalam Manajemen Konflik, RSUP Fatmawati, Jakarta Selatan.

Keputusan Kementerian Kesehataan Nomor 81 Tahun 2004 tentang Pedoman Penyusunan Perencanaan Sumber Daya Manusia Kesehatan di Tingkat Provinsi, Kabupaten/Kota serta ditingkat Rumah Sakit,

Marquis \& Huston., 2000. Leadership Role and Management in Nursing : Theory and Application, Philadelphia : Lippincott.

Mugiyanti, Sri, 2016. Manajemen Kepemimpinan Dalam Praktek Keperawatan, Kementerian Kesehatan RI, Jakarta Selatan.

Pemprov DKI Jakarta. 2020. Instruksi Gubernur DKI Jakarta Nomor 55 tahun 2020 tentang Peningkatan Kapasitas Perawatan bagi Pasien Corona Virus Disease 2019 (Covid-19) Pada Rumah Sakit Umum Daerah dan Rumah 
Sakit Rujukan Penanggulangan Corona Virus Disease 2019 (Covid-19)

Peraturan Menteri Kesehatan RI Nomor 10 Tahun 2015 tentang Standar Pelayanan Keperawatan di Rumah Sakit Khusus.

Supyono, 2020. Pengelolaan SDM Keperawatan Selama Pandemi COVID-19, Kementerian Kesehatan RI, Jakarta.

Tuwu, Darwin, 2020. Kebijakan Pemerintah Dalam Penanganan Pandemi Covid19 . Jurusan Ilmu Kesejahteraan Sosial FISIP Universitas Halu Oleo, Kendari Welda, Astefany, 2017. Analisa Beban Kerja Serta Perhitungan Kebutuhan Perawat di Instalasi Gawat Darurat RSUD Pasar Minggu, Fakultas Kesehatan Masyarakat Universitas Indonesia, Depok.

\begin{tabular}{|l|l|}
\hline Submission & $09-06-2021$ \\
\hline Review & $17-07-2021$ \\
\hline Accepted & $23-09-2021$ \\
\hline Publish & $29-10-2021$ \\
\hline DOI & 10.29241 jmk.v7i2.631 \\
\hline Sinta Level & 3 (Tiga) \\
\hline
\end{tabular}

